Danijela Šegedin Borovina

University of Split

Croatia
2017, Vol. 14 (1), 75-93(126)

revije.ff.uni-lj.si/elope

doi:10.4312/elope.14.1.75-93

UDC: [811.111'243:37.091.3]:811.163.42

\title{
Croatian EFL Learners' Interlanguage Requests: A Focus on Request Modification
}

\begin{abstract}
This paper explores the development of pragmatic competence in the interlanguage of Croatian learners of English as a foreign language (EFL) at three proficiency levels (beginner, intermediate and advanced). It investigates the way Croatian learners of English as a foreign language (EFL) use internal and external supportive moves to modify their requests. Data were collected using an oral Discourse Completion Test consisting of ten school-related situations. The research participants were 60 EFL learners aged between 11 and 18. The coding categories developed in the Cross-Cultural Speech Act Realization Project (CCSARP, Blum-Kulka et al. 1989) and adapted by Schauer (2009) were used to analyse the data. Overall results indicated that the request production of EFL learners showed little variation regarding the type of modification and frequency of their use. Results also indicated weak evidence of pragmalinguistic development across levels, particularly in the use of grounders. The infrequent use of request modification suggests that pragmatic instruction should be included in FL classrooms to facilitate the development of L2 pragmatic ability.
\end{abstract}

Keywords: pragmatic competence; Croatian EFL learners; interlanguage requests; internal modification; external modification

\section{Izražanje zahtev hrvaških učencev angleščine kot tujega jezika v vmesnem jeziku s poudarkom na modifikaciji}

\author{
POVZETEK
}

Članek obravnava razvoj pragmatične kompetence hrvaških učencev angleščine kot tujega jezika na treh ravneh jezikovne zmožnosti v vmesnem jeziku [interlanguage]: začetni, nadaljevalni in višji. Proučuje uporabo notranjih in zunanjih podpornih strategij, s katerimi hrvaški učenci angleščine kot tujega jezika modificirajo izražanje zahtev. Podatke smo zbirali s testom dopolnjevanja diskurza, ki ga je sestavljalo deset s šolo povezanih situacij. V raziskavi je sodelovalo 60 učencev angleščine kot tujega jezika, starih od 11 do 18 let. $\mathrm{V}$ analizi smo uporabili kodirne kategorije, ki so jih razvili za potrebe projekta Cross-Cultural Speech Act Realization Project (CCSARP, Blum-Kulka et al. 1989). Slednje je pozneje prilagodil Schauer (2009). Rezultati so pokazali, da učenci pri izražanju zahtev uporabljajo omejeno število variacij glede na vrsto modifikacije in na pogostost njihove uporabe. Rezultati so obenem nakazali šibek pragmajezikovni razvoj glede na raven jezikovne zmožnosti, predvsem pri uporabi t.i. grounders, s katerimi utemeljujejo zahteve. Na podlagi teh rezultatov predlagamo večje vključevanje pragmatičnih vsebin v pouk tujega jezika za spodbujanje pragmatične zmožnosti v L2.

Ključne besede: pragmatična zmožnost; hrvaški učenci angleščine kot tujega jezika; izražanje zahtev v vmesnem jeziku; notranja modifikacija; zunanja modifikacija 


\section{Croatian EFL Learners' Interlanguage Requests: A Focus on Request Modification}

\section{Introduction}

Becoming communicatively competent in the target language involves far more than acquiring the syntactic, lexical and phonological systems of that language (Richards 2006). This "missing link" has often been described as the learners' ability to use their second language in authentic communication and the ability to adjust their utterances to the sociocultural requirements of a communicative situation. Experience teaches us that this "bridge" between "the classroomacquired" second language knowledge and the use of language in real life is the most difficult to cross in foreign language learning. In various models of communicative competence this "missing link" has been called pragmatic competence (see for example Bachman 1990; Bachman and Palmer 1996; Council of Europe 2001). The main aim of this paper is thus to examine the development of pragmatic competence in the interlanguage of Croatian EFL learners by analysing the use of internal and external modification in their $\mathrm{L} 2$ requests.

The present study is structured in the following way: section 2 provides the theoretical background of the study, focusing on pragmatic competence, interlanguage pragmatics and the speech act of requesting. This section includes a brief overview of relevant studies and presents the typology of speech act modifiers that were used. Section 3 presents the research methodology, including the participants, instrument and data collection procedure, while section 4 presents the results and discussion. Section 5 concludes the paper, suggesting directions for future research while also addressing the study's limitations.

\section{Theoretical Background}

\subsection{Pragmatic Competence and Interlanguage Pragmatics}

In Bachman and Palmer's model of communicative language ability (Bachman and Palmer 1996), pragmatic knowledge appears for the first time as one of two key components of this ability. The other component of the communicative language ability is organizational knowledge, which comprises grammatical and textual knowledge. Pragmatic knowledge includes sociolinguistic and functional knowledge and enables us "to create or interpret discourse by relating utterances or sentences and texts to their meaning, to the intentions of language users, and to relevant characteristics of the language use setting" (Bachman and Palmer 1996, 69). Sociolinguistic knowledge refers to the knowledge of sociolinguistic conventions for creating and interpreting utterances which are acceptable in a particular communicative situation. Functional knowledge refers to "knowledge of pragmatic conventions for expressing acceptable language functions and for interpreting the illocutionary power of utterances or discourse" (Bagarić and Mihaljević Djigunović 2007, 99). In the Common European Framework of Reference for Languages (Council of Europe 2001), communicative language competence includes linguistic, sociolinguistic and pragmatic competences. Pragmatic competence comprises discourse competence, functional competence and design competence. Discourse competence is the ability of a user/learner to arrange sentences in sequence so as to produce coherent stretches of language. This component is concerned with the use of spoken discourse and written texts in communication for particular functional purposes (Council of Europe 2001, 123-29). It is important to note that each of 
these competences is described through a series of sub-competence and illustrative descriptors carefully describing the specific skills of a learner at a particular level.

Within the field of second language acquisition (SLA), the development of pragmatic competence in foreign language learners is researched as the key topic of the discipline known as interlanguage pragmatics (ILP). According to Kasper and Rose (2002, 5), ILP can be divided into two sections: the study of second language use and the study of second language learning. As the study of second language use, ILP examines how non-native speakers "comprehend and produce action in the target language." As the study of second language learning, ILP examines how L2 learners "develop the ability to understand and perform action in the target language" (Kasper and Rose 2002 , 5). The term "action" in both definitions refers to different types of speech acts. According to Economidou-Kogetsidis $(2008,112)$, there are two "central" research questions in the field of interlanguage pragmatics: one of them is how learners produce requests and other speech acts in a second language and the other refers to the linguistic means L2 learners employ for mitigating the force of their speech acts. The present study thus explores the linguistic means Croatian learners of English as a foreign language use to modify their requests.

For the purpose of this study, it is important to mention that Leech (1983) made a distinction between the areas of pragmalinguistics and sociopragmatics. Pragmalinguistics refers to the grammatical side of pragmatics and includes the resources or means used to convey specific communicative acts. These resources include direct and indirect strategies, pragmatic routines and a range of modification devices used to soften or intensify a particular speech act (MartínezFlor 2004). Sociopragmatics is defined as "the sociological interface of pragmatics" (Leech 1983 , 10). Sociopragmatics refers to social factors such as the degree of imposition and the status and social distance between interlocutors which influence the choice and performance of a particular speech act. The present study deals with the pragmalinguistic aspects of learners' requests. Sociopragmatic variables are included in the research methodology, but only as a way of providing a more precise description of request scenarios (see section 3.3). ${ }^{1}$

\subsection{The Speech Act of Requesting}

Requests are very frequent in everyday communication, both inside and outside the foreign language classroom. Requesting involves much more than just choosing an appropriate linguistic form: the speaker must take into account the socio-cultural context of the communicative situation which, among other factors, includes the social status of the interlocutor, the impositive nature of this speech act as well as the social distance between the interlocutors (Brown and Levinson 1987). According to Halupka-Rešetar (2014), inappropriate use of requests by foreign language learners may lead to misunderstanding or even a complete breakdown of communication. Kasper and Rose (2002) state that foreign language learners need a significant amount of time to acquire the ability to choose linguistic forms appropriate to a certain speech situation. The development of the pragmatic aspects of interlanguage requests is particularly problematic in the context of foreign language classrooms. Specifically, the pragmatic aspects of any linguistic form are addressed to a limited extent in this setting (Barron 2000). This means that learners of a foreign language are in a complex situation where they need to use requests frequently inside and, presumably, outside the classroom, but are often unsure which linguistic device to choose. This explains why requests have attracted researchers' attention more than any other speech act within the field of interlanguage pragmatics.

For a more detailed discussion on sociopragmatic variables, see Brown and Levinson (1987, chapters 3, 4 and 5). 
According to Searle (1979), requests belong to the category of directives. Requests are "attempts... by the speaker to get the hearer to do something. They may be very modest 'attempts' as when I invite you to do it or suggest that you do it, or they may be very fierce attempts as when I insist that you do it" (Searle 1979, 13). Requests represent attempts by the speaker to engage the hearer in some future action which would be beneficial for the speaker (Barron 2000). In other words, the illocutionary point of requests is to get the world to match the words (Searle 1979). Requests can also be described as pre-events, as they express the speaker's expectation toward some prospective action (Blum-Kulka et al. 1989). Asking somebody to do something for you is often impositive and may be interpreted by a hearer as an intrusion upon his or her "territory." Requests are thus often described as non-hearer supportive (Barron 2000) or as face-threatening (Brown and Levinson 1987). According to Brown and Levinson $(1987,65)$ "certain kinds of acts intrinsically threaten face, namely those acts that by their nature run contrary to the face wants of the addressee and/or of the speaker." Blum-Kulka et al. (1989, 11-12) state that "hearers can interpret requests as intrusive impingements on freedom of action, or even as a show in the exercise of power; speakers may hesitate to make the request for fear of exposing a need or risking the hearer's loss of face. The abundance of linguistic options available for requesting behaviour testifies to the social intricacies associated with choice in mode of performance."2 Requests call for redressive action and require mitigation in order to compensate for their impositive effect on the hearer (Blum-Kulka et al. 1989). The speaker can minimize the impositive nature of the request by choosing an indirect strategy of requesting instead of a direct one and by "softening" the requesting strategy further by adding internal and external modification to the request.

According to the CCSARP Coding Manual, the core of the request sequence is known as the Head Act, "a minimal unit which can realize a request" (Blum-Kulka et al. 1989, 275). It is the only obligatory part of the request. The Head Act can be realized by using different request strategies, which can be defined as the obligatory choice of the level of directness. There are three main request strategies: direct, conventionally indirect and non-conventionally indirect strategies (for a more detailed account of this categorization, see Blum-Kulka et al. 1989). The non-obligatory parts of a request are supportive moves which modify the impact of the request by either aggravating or mitigating its force. Different types of request modification are presented in the next section.

\subsection{Request Modification}

In addition to selecting a particular request strategy, learners can decrease or increase the force of their request by using internal and/or external modification. The categories of the classification

This comment was made in the first chapter of the book entitled Cross-Cultural Pragmatics: Requests and Apologies (Blum-Kulka, House and Kasper 1989). It presented the results of the large-scale project known as the CrossCultural Speech Act Realization Project (CCSARP). The project was set up by the authors to investigate crosscultural and intralingual variation in two speech acts: requests and apologies. The general goal of the project was to establish the patterns of requests and apology realizations under certain social situations across different languages and cultures and between native and non-native speakers. The study collected data from college students speaking seven different languages or language varieties (Australian English, American English, British English, Canadian French, Danish, German and Hebrew). The instrument used in this project (Discourse-Completion Test or DCT) was later used in its original or modified form by numerous researchers in the field of interlanguage pragmatics. The project is also valuable for its classification of request strategies into nine categories, which ranged from the most direct to the least direct, as well as for the classification of internal and external modification strategies into categories. This classification is frequently used in interlanguage request studies. 
scheme used in this study are based on the CCSARP Coding Manual (Blum-Kulka et al. 1989) and Schauer's (2009) adaptations of this manual. Some of the categories which appear in the abovementioned taxonomies did not appear in our corpus and thus were excluded from the current analysis (for example, aggravating supportive moves).

Internal modifiers, as their name implies, are found within the Head Act and are a part of the request proper. Internal modifiers are lexical and syntactic devices which are used by the speaker to mitigate the force of the request. External modifiers (also called supportive moves) are elements that are "outside" the request Head Act. They either precede or follow the request Head Act and their function is to modify the illocutionary force of the request (Flores Salgado 2008). Tables 1 and 2 give the taxonomy of internal and external modification used in this research. Only those modifiers which were found in the corpus are included in the overview. The examples provided in the tables were found in the corpus collected for the purposes of this study.

TABLE 1. Overview of internal modifiers.

\begin{tabular}{|c|c|c|c|}
\hline \multicolumn{4}{|c|}{$\begin{array}{l}\text { Internal modification } \\
\text { (syntactic and lexical/phrasal downgraders) }\end{array}$} \\
\hline & Name & Definition/function & Example \\
\hline 1. & $\begin{array}{l}\text { Conditional } \\
\text { clause }\end{array}$ & $\begin{array}{l}\text { employed by speakers to distance } \\
\text { themselves from the request }\end{array}$ & $\begin{array}{l}\text { I'd be grateful if you could help } \\
\text { me with that. }\end{array}$ \\
\hline 2. & $\begin{array}{l}\text { Politeness } \\
\text { marker }\end{array}$ & $\begin{array}{l}\text { "an optional element added to a request } \\
\text { to bid for co-operative behaviour" } \\
\text { (Blum-Kulka et al. 1989, 283) }\end{array}$ & $\begin{array}{l}\text { Can you please explain me } \\
\text { some maths problems? }\end{array}$ \\
\hline 3. & $\begin{array}{l}\text { Past tense } \\
\text { Modals }\end{array}$ & $\begin{array}{l}\text { past tense forms such as could or would } \\
\text { make the request appear more polite } \\
\text { (Schauer 2009) }\end{array}$ & $\begin{array}{l}\text { Would you like to sit with me } \\
\text { this class? }\end{array}$ \\
\hline 4. & $\begin{array}{l}\text { Marked } \\
\text { Modality }\end{array}$ & $\begin{array}{l}\text { might and may make the request appear } \\
\text { more tentative (Schauer 2009) }\end{array}$ & $\begin{array}{l}\text { May I borrow your notebook } \\
\text { please? }\end{array}$ \\
\hline 5. & $\begin{array}{l}\text { Consultative } \\
\text { Device }\end{array}$ & $\begin{array}{l}\text { "expressions by means of which the } \\
\text { speaker seeks to involve the hearer } \\
\text { directly bidding for cooperation" (Blum- } \\
\text { Kulka et al. 1989, 283) }\end{array}$ & $\begin{array}{l}\text { Would you mind to give me one } \\
\text { chewing gum? }\end{array}$ \\
\hline
\end{tabular}

TABLE 2. Overview of external modifiers.

\begin{tabular}{|l|l|l|l|}
\hline \multicolumn{2}{|c|}{ External modification } \\
\hline & Name & Definition/function & Example \\
\hline 1. & Alerter & $\begin{array}{l}\text { linguistic device that is used to get the } \\
\text { interlocutor's attention; precedes the } \\
\text { Head Act (Schauer 2009) }\end{array}$ & Hey can you help me with this? \\
\hline
\end{tabular}




\begin{tabular}{|c|c|c|c|}
\hline 2. & Preparator & $\begin{array}{l}\text { "short utterance that intends to prepare } \\
\text { the interlocutor for the request; can } \\
\text { follow or substitute the Alerter" (Schauer } \\
2009,92)\end{array}$ & $\begin{array}{l}\text { Do you have some glue and can } \\
\text { I borrow it-please? }\end{array}$ \\
\hline 3. & Grounder & $\begin{array}{l}\text { "The speaker gives reasons, explanations, } \\
\text { or justifications for his or her request, } \\
\text { which may either precede or follow it" } \\
\text { (Blum-Kulka et al. 1989, 287). }\end{array}$ & $\begin{array}{l}\text { Hey, I am celebrating my } \\
\text { birthday today. Can you give - } \\
\text { can you come? }\end{array}$ \\
\hline 4. & $\begin{array}{l}\text { Obtaining a pre- } \\
\text { commitment }\end{array}$ & $\begin{array}{l}\text { speaker precedes the request by an } \\
\text { utterance that represents an attempt to } \\
\text { get a pre-committal }\end{array}$ & $\begin{array}{l}\text { Could you do something for } \\
\underline{m e} \text { ? }\end{array}$ \\
\hline 5. & Apology & $\begin{array}{l}\text { "The speaker apologizes for posing } \\
\text { the request and/or for the imposition } \\
\text { incurred" (Halupka-Rešetar 2014, 34). }\end{array}$ & $\begin{array}{l}\text { I am sorry, can you give me } \\
\text { your notebook? I need it. }\end{array}$ \\
\hline 6. & Combination & $\begin{array}{l}\text { The speaker uses a combination of two } \\
\text { or more external modification devices to } \\
\text { modify his or her request. }\end{array}$ & $\begin{array}{l}\text { Do you have that maths task? } \\
\text { I've lost the notebook where I } \\
\text { wrote it... so I'd be grateful if } \\
\text { you could help me with that. }\end{array}$ \\
\hline
\end{tabular}

\subsection{Comparative and Cross-Sectional Studies on Request Modification: An Overview}

In this section the studies examining the learners' use of internal and external modifying devices are briefly reviewed. The majority of these studies to date have taken a comparative focus, examining and highlighting differences in request production between learners of a language and native speakers (Faerch and Kasper 1989; Economidou-Kogetsidis 2008; EconomidouKogestidis 2012). Studies with a cross-sectional design include participants at various stages of language proficiency (Rose 2009; Göy, Zeyrek and Otcu 2012; Halupka-Rešetar 2014). This review will be limited to comparative and cross-sectional studies in which the participants were learners of English as a foreign language.

As a part of the CCSARP project, Faerch and Kasper (1989) examined internal and external modification in the interlanguage request realization of Danish learners of English and compared the results to the data obtained from the native speaker corpus. Compared to native speakers, learners overused the politeness marker please and showed a tendency towards overcomplexity in the use of syntactic downgraders. Grounders were the single most frequently used external modifier. The learners also showed a tendency towards "verbosity" which was defined as "preference for propositional explicitness where native speakers would prefer shorter and more implicit modes of expression” (Faerch and Kasper 1989, 245).

Economidou-Kogetsidis (2008) examined the patterns of internal and external modification in the request production of advanced Greek EFL learners, comparing the results with those of native speakers of British English. The results have shown that Greek learners generally underused lexical and phrasal downgraders, especially the politeness marker please and consultative devices. On the other hand, the learners overused disarmers and preparators. The author concluded that the underuse of the politeness marker and consultative devices was a result of the influence 
of the learners' mother tongue. In Greek culture, these expressions are intuitively associated with formality rather than politeness and therefore are less readily used by Greek speakers. In a later study, Economidou-Kogestidis (2012) also examined patterns of internal and external modification but this time in requests made by low proficiency EFL learners. The results were compared to those of American English speakers. The results again indicated that the learners significantly underused internal modification and showed a preference for external modification, especially grounders. Economidou-Kogetsidis (2012) pointed out that internal modification may not be a part of low proficiency learners' pragmalinguistic repertoire because of its complexity and the need for additional processing. External modification, according to the author, is syntactically less complex and thus acquired more easily. The author also emphasized the need for the early introduction of pragmatic instruction in EFL classrooms.

In 2009 Rose examined the use of alerters, supportive moves and the politeness marker please in the interlanguage requests of secondary school EFL learners (aged from 13 to 17) from Hong Kong. The aim of this study was to look for evidence of pragmalinguistic and sociopragmatic development across three groups of learners. The results showed that the mean frequency of alerters increased with the proficiency level, while the frequency of please on the other hand decreased with the proficiency level. Learners in the advanced group were to a limited extent using supportive moves to mitigate their requests. Rose (2009) concluded that the appearance of supportive moves indicated the beginning of the pragmatic expansion stage in request development.

Göy, Zeyrek and Otcu (2012) investigated the development of internal request modification in requests made by Turkish learners of English at two proficiency levels (beginners and higher proficiency learners). In line with the previous studies, results have shown that beginner learners underused syntactic and lexical/phrasal downgraders. Higher proficiency learners showed very slow development in the use of both subtypes of internal modification. The authors stated that these results suggested weak attentional control over pragmatic knowledge and that the reason for the slow pragmatic development must be multicausal.

Halupka-Rešetar (2014) examined the types and frequency of usage of internal and external modification in the request production of ESP students at an intermediate proficiency level. Learners' request production showed limited variation with respect to the type of modification and the frequency of their use. Among the supportive moves, grounders were used the most frequently, and almost exclusively. The politeness marker please and conditional clauses were most frequently used among internal modification.

It must be noted that most of the studies on interlanguage request modification have concentrated on foreign language learners of intermediate and/or advanced language proficiency. "Little research has been conducted on low proficiency FL learners in relation to their interlanguage pragmatic production. Further research is needed with adult learners at lower proficiency levels and in a foreign language context in order to examine the stages of learners pragmatic development and the pragmalinguistic features of learners' speech act production during this low proficiency stage. Such an examination will provide a more complete picture of $\mathrm{L} 2$ speech act performance" (Economidou-Kogetsidis 2012, 164). This comment has been singled out precisely because this is the aim of the present study: to describe the internal and external modification strategies in request production by learners of English as a foreign language at three levels of proficiency, including low-proficiency, intermediate and advanced learners of English. The participants at the beginning and intermediate levels of proficiency are, however, not adults but young learners of English (aged between 11 and 14). This paper is thus an attempt to add to the growing body of 
knowledge on FL speech act performance by extending cross-sectional work to Croatian learners of English.

\section{The Study}

\subsection{Aim}

Following Halupka-Rešetar (2014) and Rose (2009), the research questions that guided this study were as follows:

1. What types of internal and external modification devices are used most frequently by Croatian leaners of English as a foreign language at three levels of proficiency (beginner, intermediate and advanced)?

2. Is there evidence of pragmalinguistic development?

This study can be described as cross-sectional and pseudo-longitudinal, as its main goals were to analyse the "current state" of the learners' ability to modify the speech act of requesting and to look for evidence of pragmalinguistic development across proficiency levels.

\subsection{Participants}

The participants were learners from secondary and elementary schools in two Croatian counties, all native speakers of Croatian, who were selected from three proficiency levels: beginner, intermediate, and advanced (20 learners per group, 60 in total). The beginners' group included Grade 5 learners (age: 11 years) who had at that point been learning English for 4 years (since Grade 1). The intermediate group comprised of Grade 8 learners (age: 14 years) who had been learning English for 8 years. The advanced group included secondary school learners (age: 18 years) who had been learning English for 12 years (they were in their final year of secondary school, Grade 4).

There was initially a plan to use a proficiency test to measure the learners' English proficiency. However, this was not possible because there was not sufficient access granted to the participants for the placement test, questionnaire development and final data collection. It is, however, common practice in ILP request studies to use placement in language courses to identify general levels of language proficiency and, consequently, general levels of pragmatic competence (see for example Félix-Brasdefer 2007, 260). The decision was made to use the time available to develop the research instrument and collect relevant data. Following similar existing research (Rose 2009; Félix-Brasdefer 2007), the learners' respective grades were equated to proficiency levels (grade 5 learners-beginner group; grade 8 learners-intermediate group; grade 4 learners/ secondary school-advanced group). ${ }^{3}$

\footnotetext{
According to the Code of Ethics for Research Involving Children (published by the Croatian Council for Children in 2003), parental consent is required for children under the age of 14 . In accordance with this legal requirement, written parental consent for all participants under 14 was obtained via parent-teacher meetings. Children older than 14 (secondary school learners) gave their own written consent for their participation in the research. All participants were informed about the research in terms appropriate to their age. They were also told that their data would be treated as strictly confidential.
} 


\subsection{Data Collection and Analysis}

EFL learners' responses were elicited using the form of an oral discourse completion test (DCT). The questionnaire contained 10 different school-related situations and was developed through the processes of exemplar generation and metapragmatic assessment (for a detailed description of the procedure, see Rose 2009). The ten situations reflect different relationships in the classroom (learner asking something from another learner, learner requesting something from a teacher), different degrees of imposition (low-imposition requests/high-imposition requests) and difference in social dominance (for example, a learner posing a high imposition request to the teacher vs. a learner posing a high imposition request to his/her peer). The corpus collected for the purpose of the present study contained 480 requests. Table 3 provides an overview of the ten request scenarios selected for this study (for a full description of the scenarios, see Appendix 1).

TABLE 3. Request scenarios.

\begin{tabular}{|l|l|l|}
\hline $\mathbf{I t e m}$ & Hearer & Description \\
\hline $\mathbf{1}(=, \mathrm{L})$ & learner & borrow glue \\
\hline $\mathbf{2}(\mathrm{HD}, \mathrm{H})$ & teacher & postpone written exam \\
\hline $\mathbf{3}(=, \mathrm{H})$ & learner $)$ & invite to birthday party \\
\hline $\mathbf{5}(\mathrm{HD}, \mathrm{L})$ & learner & borrow notebook \\
\hline $\mathbf{6}(=, \mathrm{H})$ & teacher & repeat question \\
\hline $\mathbf{7}(=, \mathrm{L})$ & learner & explain maths exercise \\
\hline $\mathbf{8}(\mathrm{HD}, \mathrm{H})$ & learner & sit together \\
\hline $\mathbf{9}(\mathrm{HD}, \mathrm{H})$ & teacher & postpone oral exam \\
\hline $\mathbf{1 0}(=, \mathrm{L})$ & teacher & volunteer for oral exam \\
\hline
\end{tabular}

$H D$ indicates hearer dominance; = indicates equal speaker-hearer status; L indicates low imposition requests; $H$ indicates high imposition requests

Data collection was carried out in Croatian to ensure that the participants could understand the scenarios and task. Participants were provided with a questionnaire containing the request scenarios, which were described in Croatian. The task was carefully explained to the learners, and the first request scenario was done as an example to make sure learners knew what was expected of them. Participants were given audio voice recorders and taught how to operate them. They completed their questionnaires individually by recording their answers in English. Participants were also given an option to say "I don't know" if they did not know how to formulate a request (for more on opting out, see Rose and Ono 1995). Data were transcribed for coding and classified according 
to the taxonomies provided in tables 1 and 2, with the Statistical Package for the Social Sciences (SPSS 20.0) used to analyse the data. The total frequency and percentage of internal and external modification strategies were calculated. Where possible, the chi-square test was used to establish whether differences among the three groups of learners were significant. In addition, examples from the corpus were provided for most of the modification strategies found in learners' requests.

\section{Results and Discussion}

\subsection{Results Regarding Learners' Overall Use of Internal Modification}

Table 4 displays the overall results for the use of internal modification strategies across three proficiency levels.

TABLE 4. Overall results for the use of internal modification across three proficiency levels.

\begin{tabular}{|l|c|c|}
\hline Internal modification & f & $\%$ \\
\hline syntactic downgraders & & \\
\hline conditional clause & 6 & $1.9 \%$ \\
\hline lexical and phrasal downgraders & & \\
\hline politeness marker please & 195 & $61.5 \%$ \\
\hline past tense modals & 102 & $32 \%$ \\
\hline marked modality & 3 & $1 \%$ \\
\hline consultative device & 8 & $2.5 \%$ \\
\hline Combination & 3 & $1 \%$ \\
\hline TOTAL & $\mathbf{3 1 7}$ & $\mathbf{1 0 0} \%$ \\
\hline
\end{tabular}

Table 4 reveals that the participants did not use syntactic downgraders very frequently in their requests. Eight different types of syntactic downgrader (interrogative, negation of preparatory condition, subjunctive, aspect, tense etc.) were enumerated in the CCSARP Coding Manual (Blum-Kulka et al. 1989). However, Croatian EFL learners used only the conditional clause to syntactically modify their requests. Grade 5 learners (beginners) did not use syntactic modification at all. In Grade 8 (intermediate learners), the conditional clause appeared only once, while Grade 4 learners (secondary school, advanced group) used the conditional clause in five requests. The following are examples of its use:

Please, teacher, if you could not ask me this... this day today... I didn't learn very well for today. (learner $45,{ }^{4}$ request scenario 8 - postponing oral exam, advanced group)

\footnotetext{
4 In the corpus collected for the purpose of this study, numbers were used instead of names to protect learners' anonymity.
} 
I would like to ask you if you could... if you could ask me tomorrow. (learner 46, request scenario 8 - postponing oral exam, advanced group)

The low frequency of syntactic downgraders is in line with the results of various other studies (Economidou-Kogetsidis 2012; Göy, Zeyrek and Otcu 2012; Hassall, 2012; Halupka-Rešetar 2014) which found that the underuse of syntactic downgraders is a typical feature of L2 request production. Faerch and Kasper $(1989,237)$ observe that "the mitigating function of syntactic downgraders is not inherent in the grammatical meaning of syntactic structures: it is a pragmatic, "acquired" meaning that derives from the interaction of the structure with its context and requires... extra inferencing capacity on the part of the addressee." The politeness function of syntactic downgraders is thus implicit rather than explicit. Woodfield $(2012,22)$ states that syntactic modifiers "may take time to acquire": it is possible that the development of these structures in learners' request production depends on learners' noticing the pragmatic aspects of these structures. Göy et al. (2012) suggest that pragmatic development starts with a period of the under-use of syntactic downgraders. Internal modification seems to be "particularly sensitive to level of proficiency and may not be part of low proficiency learners' pragmalinguistic repertoire" (Woodfield and Economidou-Kogetsidis 2012, 5). These conclusions are applicable to our learners' request production, although the use of conditional sentences in the advanced group may be accepted as a very weak sign of pragmalinguistic development in the formulation of interlanguage requests.

\subsection{Results regarding Learners' Use of Lexical and Phrasal Modifiers}

Lexical and phrasal downgraders were used far more frequently than syntactic modifiers. The politeness marker please and past tense modals (could and would) were used in more than $93 \%$ of requests containing any kind of internal modification. This result is also in line with previous similar studies (Schauer 2009). Table 5 displays the frequency and percentage of please and past tense modals by proficiency level. Other lexical and phrasal downgraders (marked modality, consultative device, combination) were used infrequently and thus are not included in Table 5.

TABLE 5. Internal modification: lexical and phrasal downgraders.

\begin{tabular}{|l|c|c|c|c|}
\cline { 2 - 5 } \multicolumn{4}{c|}{} & \multicolumn{4}{l|}{ Lexical and phrasal downgraders } \\
\hline Level & $\begin{array}{c}\text { could } \\
\mathrm{f}(\%)\end{array}$ & $\begin{array}{c}\text { would } \\
\mathrm{f}(\%)\end{array}$ & $\begin{array}{c}\text { please } \\
\mathrm{f}(\%)\end{array}$ & TOTAL \\
\hline beginner & $1(2 \%)$ & $1(2 \%)$ & $33(16.9 \%)$ & 35 \\
\hline intermediate & $39(76 \%)$ & $12(23.5 \%)$ & $72(36.9 \%)$ & 123 \\
\hline advanced & $11(21.6 \%)$ & $38(74.5 \%)$ & $90(46.2 \%)$ & 139 \\
\hline TOTAL & 51 & 51 & 195 & 297 \\
\hline Chi-square test & N/A & N/A & $\begin{array}{c}\chi^{2}=26.123 \\
\mathrm{p}<0.001^{*}\end{array}$ \\
\hline
\end{tabular}

$N / A=$ expected frequencies are less than 5

*hypothesis confirmed at $p \leq 0.05$ 
The past tense modals could and would were much less frequently used than the politeness marker please. Beginner learners used both modals only once, while their use in advanced and intermediate groups follows a contrasting pattern: intermediate learners used could in 39 instances, while advanced learners used this modal in 11 requests. On the other hand, intermediate learners used would in 12 requests, while the frequency of use in advanced requests increased to 38 .

A statistically significant difference was found in the use of please. The difference was statistically significant at a $\mathrm{p} \leq 0.05$ level of the Chi-square test. As table 5 shows, the use of please steadily increased across levels, from 33 instances of this marker in beginner requests to 90 instances in advanced requests. This result is in contrast to the results of previous similar studies. The results of research carried out by Hill (1997) and Rose (2009) have shown that the frequency of please decreased with the level of proficiency, prompting the authors to describe this occurrence as a development in the direction of the native speaker norm. The decrease in the use of please meant that the advanced group used other lexical and phrasal modifiers more frequently. In order to further examine the use of please in our corpus, I have also analysed the position of please within learners' requests. According to Hill (1997), the politeness marker can be used in sentence-initial, sentence-final and the intra-sentential position. The positioning of the politeness marker at the end of the request or within the request was interpreted by Hill (1997) as a sign of pragmatic development. Table 6 displays the positioning of please across proficiency levels.

TABLE 6. Positioning of politeness marker across proficiency levels.

\begin{tabular}{|l|c|c|c|c|}
\cline { 2 - 5 } \multicolumn{1}{|c|}{} & \multicolumn{2}{l|}{ Positioning of please } \\
\hline Level & $\begin{array}{c}\text { sentence-initial } \\
\mathrm{f}(\%)\end{array}$ & $\begin{array}{c}\text { intra-sentential } \\
\mathrm{f}(\%)\end{array}$ & $\begin{array}{c}\text { sentence-final } \\
\mathrm{f}(\%)\end{array}$ & TOTAL \\
\hline Beginner & $10(12.8 \%)$ & $17(23.6 \%)$ & $6(13.3 \%)$ & 33 \\
\hline Intermediate & $23(29.5 \%)$ & $23(31.9 \%)$ & $26(57.8 \%)$ & 72 \\
\hline Advanced & $45(57.7 \%)$ & $32(44.4 \%)$ & $13(28.9 \%)$ & 90 \\
\hline Total & $78(100 \%)$ & $72(100 \%)$ & $45(100 \%)$ & 195 \\
\hline
\end{tabular}

The results presented in table 6 are somewhat inconclusive. It is difficult to establish any kind of pattern regarding the positioning of please or confirm the results and conclusions of previous studies. It is interesting to note that intermediate learners used please in all three positions in almost equal proportions, while the frequency of use in advanced learners' requests decreased steadily from a sentence-initial please to a sentence-final please. The intermediate group used please in the sentence-final position more frequently than the advanced group, while the advanced group used please in the middle of the sentence more frequently than the intermediate group. Both groups used the politeness marker in all positions more frequently than the beginner group. Further research is necessary to explain these patterns of use, that is, to explain why the frequency of use did not decrease with the level of proficiency. 
There are several reasons for the frequent use of please across all proficiency levels. The learners' preference for the politeness marker please can be explained by its "double function as illocutionary force indicator and transparent mitigator" (Faerch and Kasper 1989, 233). Faerch and Kasper $(1989,233)$ also claim that learners tend to choose please to modify their requests because they want to "adhere to the conversational principle of clarity, choosing explicit, transparent, unambiguous means of expression rather than implicit, opaque, and ambiguous realizations. These qualities are exactly fulfilled by politeness marker." There are two key aspects of please which make it a preferable choice in requesting. The first aspect is "the ease" with which please becomes part of a request: it can precede the request proper as "an introduction" to the request; it can be placed at the end of the request in order to emphasize the illocutionary force of the request and decrease its impositive force (Trosborg 1995). The politeness marker please is syntactically and pragmatically fairly simple and requires minimal capacity for psychological processing. Another possible reason for the frequent use of please in learner requests may be the effect of formal instruction. Please appears relatively early in classroom discourse and EFL textbooks. The use of please thus seems to follow the path of learners from other L1 backgrounds (Göy at al. 2012). The following are examples of its use:

Please give your glue. (learner 8, request situation 1 - borrowing glue, beginner group)

Can you please teacher give the test tomorrow? (learner 22, request situation 2-postponing written exam, intermediate group)

Can you please delete the blackboard instead of me? (learner 51, request situation 10 cleaning the blackboard, advanced group)

To sum up, the frequent use of the politeness marker please and past tense modals is not "unexpected" since these lexical downgraders are not "difficult to incorporate in a sentence and are taught very early in the language classroom" (Schauer 2012, 170). On the other hand, the absence of other types of internal modification points to the lack of linguistic means at all proficiency levels.

As mentioned earlier, other lexical and phrasal downgraders were rarely used across all proficiency levels. For example, there were only eight instances of a consultative device in the whole corpus of learners' requests. It is worth mentioning that only advanced learners used this type of modification in their requests. The following are examples of its use:

Please, teacher, would you be so kind and tell me your question again? (learner 40, request situation 5 - repeating the question, advanced group)

Would you be so kind and explain me this task? (learner 49, request situation 6 - explaining a maths exercise, advanced group)

Would you be so kind and not interrogate me this lessons? (learner 41, request situation 10 cleaning the blackboard, advanced group)

The appearance of the consultative device in advanced requests may be interpreted as a sign of pragmalinguistic development. However, it was noted by the author that the advanced groups' teacher used the expression would you be so kind relatively frequently. As can be seen from the above examples, some of the learners have incorporated this expression into their interlanguage and have been using it in hearer-dominant and high-imposition situations. 


\subsection{Results regarding Learners' Use of External Modification}

The group analysis for external modification use in the requests of Croatian EFL learners is summarized in Table 7.

TABLE 7. Frequencies and percentages of overall external modification use.

\begin{tabular}{|l|c|c|c|c|c|c|}
\cline { 2 - 7 } \multicolumn{1}{c|}{} & \multicolumn{6}{c|}{ External modification } \\
\hline Level & alerter & preparator & grounder & $\begin{array}{c}\text { obtaining } \\
\text { a pre-com- } \\
\text { mitment }\end{array}$ & apology & combination \\
\hline Beginner & $6(4.5 \%)$ & 0 & 0 & 0 & 0 & 0 \\
\hline Intermediate & $53(40.1 \%)$ & 0 & $16(40 \%)$ & 0 & 0 & 0 \\
\hline Advanced & $73(55.3 \%)$ & 3 & $24(60 \%)$ & 1 & 3 & 8 \\
\hline Total & $132(100 \%)$ & 3 & $40(100 \%)$ & 3 & 1 & 8 \\
\hline
\end{tabular}

With the exception of alerters and grounders, external modifiers appeared relatively infrequently in the participants' responses. The use of alerters increases across levels, with beginning-level learners using this modifier in 6 instances and advanced-level learners in 73 instances. Alerter is also the only type of external modifier used by beginners.

The results have shown that advanced learners used a greater variety of external modification devices than intermediate and beginner-level learners. In addition to 73 alerters and 24 grounders, advanced learners' requests also featured one instance of obtaining a pre-commitment, three preparators, three apologies and eight requests in which the learners used a combination of different types of external modification. Due to the low frequencies, additional statistical analysis (the Chi-square test) could not be carried out. It must be emphasized that a range of external modification devices - however limited - appeared only in the requests made by advanced learners. From the developmental perspective, the increase and variety in the use of external modification (albeit limited) may be described as development. The following are examples of obtaining a pre-commitment, apology and preparator:

Do you have some glue and can I borrow it please? (learner 57, request situation 1 borrowing glue, advanced group)

Please do me a favour and wash the board instead of me. (learner 49, request situation 10 cleaning the blackboard, advanced group)

I am sorry, can you repeat your question? (learner 60, request situation 5 - repeating the question, advanced group)

Teacher, may I ask you something? Can you please postpone the test? (learner 41, request situation 2 - postponing written exam, advanced group) 
In addition to alerters, grounders were the most frequently used external modifier in the corpus. Intermediate learners used this type of external modification in 16 requests. As mentioned above, there were 24 instances of this modifier in the replies given by the advanced-level learners. These results are in line with the results of previous similar studies (Martínez-Flor and Usó-Juan 2006; Félix-Brasdefer 2007; Woodfield 2012; Halupka-Rešetar 2014) which have shown that grounders are the most frequent supportive move in interlanguage request production. The length and the propositional content of this modification device varied with regard to the proficiency level. Intermediate-level learners used relatively short and simple grounders to support their requests. The following are examples of its use:

Teacher, can you please repeat the question? I didn't hear. (learner 34, request situation 5 repeating the question, intermediate group)

Man, I am alone. I want you to sit with me. (learner 25, request situation 7 - sitting together during lessons, intermediate group)

Could you borrow me your notebook? I forgot to take my own. (learner 21, request situation 4 - asking for notebook, intermediate group)

Yo, friend, could you sit next to me? I am lonely. (learner 37, request situation 7 - sitting together during lessons, intermediate group)

Teacher, please don't ask me this class. I couldn't learn, I was in Split. (learner 30, request situation 8 - postponing oral exam, intermediate group)

Although some of these requests were ungrammatical (the use of the verb borrow, the expression don't ask me), the main purpose was achieved: learners managed to soften the impositive force of requests by successfully incorporating a grounder in the immediate context of their requests. According to Flores-Salgado (2008, 159-60), "a restricted grammatical competence does not necessarily interfere with the pragmatic function of the form." These learners have a sufficiently developed pragmalinguistic and sociopragmatic competence to assess the contextual characteristics of a speech situation, choose an appropriate linguistic device for their requests and modify them accordingly. On the other hand, the limited scope of their grammatical competence results in mistakes. As mentioned before, the appearance of supportive moves is a sign of the beginning of the pragmatic expansion stage in interlanguage requests (Kasper and Rose 2002; Rose 2009). According to Rose $(2009,2358)$ this is "no mean feat in a context which affords so little opportunity to actually use the target language for communication."

Grounders found in advanced learners' requests were longer and more detailed than the grounders found in intermediate learners' requests. For example:

Will you clean the blackboard instead of me? I have some infection on my arms on my hands so I can't do it. (learner 43, request situation 10 - cleaning the blackboard, advanced group)

Teacher, please, can you... can you set the time of writing test next week? We have to study more this week. (learner 44, request situation 2 - postponing written exam, advanced group)

Some advanced learners showed a tendency towards verbosity:

Hey... would you come to my birthday party next week? I will -we will go to Radosici and have a really good time. Please come. I really would like to -you to be there. (learner 51, request situation 3 - birthday invitation, advanced group) 
Some of the information included in this request seems redundant and over-explicit. After posing the question in the first part of her utterance, the learner repeated the information contained in the question twice more (Please come. I really would like to -you to be there). She also supported her request by using a lengthy grounder (we will go to Radosic and have a really good time). According to Flores Salgado $(2008,161)$, the over-use of supportive moves demonstrates that these learners both "had the grammar to construct an explanation and the pragmalinguistic knowledge to mitigate the request in order to convey negative or positive politeness. The use of supportive moves was ... indicative of learners' pragmalinguistic competence, not incompetence." On the other hand, the learners did not have sufficient sociopragmatic knowledge "to assess when the use of one or more segments of a supportive move were appropriate and effective."

The over-use of supportive moves, that is, a tendency towards verbosity is described by Faerch and Kasper $(1989,245)$ as one of the "most conspicuous interlanguage-specific features." The authors suggest that this "the more the better" principle is a result of "the conflicting experience of language learners at a stage in their interlanguage development which is well beyond the threshold level of communicative competence but still a long way before near-nativeness." Learners probably want to show that they are proficient enough to produce a lengthy utterance in a foreign language.

\section{Conclusion}

The present study examined the use of internal and external modification in the requests of Croatian learners of English at three levels of proficiency. The aim was to establish the patterns of internal and external request modification use and to examine whether the learners at different levels of proficiency differ in the frequency and "quality" of modifiers they use to soften the force of their requests.

The results show that syntactic modification occurs very rarely at the intermediate and advanced levels, and does not occur at all in beginner-level requests. Please is the most frequently used lexical downgrader, followed by past tense modals. Contrary to the results of previous studies, the use of please increased with the proficiency level. Intermediate and advanced learners used please more frequently than beginner level learners. Albeit infrequently, advanced learners used some other types of lexical and phrasal downgraders (for example, consultative devices). These results may be interpreted as indicators of pragmalinguistic development in the use of lexical and phrasal downgraders.

Results for external modification also indicate a small degree of pragmalinguistic development. Specifically, learners at the intermediate and advanced levels of learning used grounders as supportive moves for their requests, which seems to indicate the beginning of the pragmatic expansion stage in request development (Kasper and Rose 2002; Rose 2009). Results have also shown that some advanced-level learners tend to be too verbose when modifying their requests, thus making the requests appear repetitive and over-explicit.

The overall conclusion of this study is that Croatian EFL learners infrequently used both types of modification (with the exception of alerters, the politeness marker please and grounders). Modification devices occurring in learners' requests are most likely the result of instruction. The fact that the range of modification devices used by learners is very limited (even at the advanced level of learning) suggests that more should be done to include pragmatic instruction in the EFL curriculum to teach pragmalinguistic forms and their sociopragmatic aspects, along 
with pragmatic functions and sequential organization of requests (Félix-Brasdefer 2007). Future research should examine the reasons for the limited use of request modifiers, including both sociopragmatic and pragmalinguistic perspectives. In addition to the usual explanation (no pragmatic instruction), other possible reasons - such as the relationship between pragmatic and grammatical competences - should be further explored.

There are several limitations of this study that need to be addressed. The first limitation concerns the use of elicited data in the examination of the EFL learners' pragmalinguistic development. It should be noted that elicited data in general cannot reflect fully how learners would react in the foreign language classroom or, indeed, in a real-life (authentic) request situation. Next, the research topic was somewhat narrow, as pragmalinguistic aspects of requesting comprise a small part of the learners' pragmatic competence. The third limitation refers to the design of the study. This study employs a cross-sectional design and consequently provides a very limited insight into learners' pragmalinguistic development. In general, a longitudinal study with a small number of participants would provide a more detailed description of learners' pragmatic development. According to Rose (2000, 29), "ILP research should routinely incorporate" both cross-sectional and longitudinal studies.

\section{References}

Bachman, Lyle F. 1990. Fundamental Considerations in Language Testing. Oxford: Oxford University Press.

Bachman, Lyle F., and Adrian S. Palmer. 1996. Language Testing in Practice: Designing and Developing Useful Language Tests. Oxford: Oxford University Press.

Bagarić, Vesna, and Jelena Mihaljević Djigunović. 2007. “Defining Communicative Competence.” Metodika 8 (1): 94-103.

Barron, Anne. 2000. “Acquiring 'Different Strokes': A Longitudinal Study of the Development of L2 Pragmatic Competence.” gfl-journal 2: 1-29. http://www.gfl-journal.de/2-2000/barron.pdf.

Blum-Kulka, Shoshana, Juliane House, and Gabriele Kasper, eds. 1989. Cross-Cultural Pragmatics: Requests and Apologies. Norwood, NJ: Ablex.

Brown, Penelope, and Stephen Levinson. 1987. Politeness. Some Universals in Language Use. Cambridge: Cambridge University Press.

Council of Europe. 2001. Common European Framework of Reference for Languages: Learning, Teaching, Assessment. Cambridge: Cambridge University Press.

Economidou-Kogetsidis, Maria. 2008. "Internal and External Mitigation in Interlanguage Request Production: The Case of Greek Learners of English." Journal of Politeness Research 4: 111-38. doi:10.1515/PR.2008.005.

—. 2012. "Modifying Oral Requests in a Foreign Language: The Case of Greek Cypriot Learners of English." In Interlanguage Request Modification, edited by Maria Economidou-Kogetsidis and Helen Woodfield, 163-202. Amsterdam/Philadelphia: John Benjamins Publishing.

Economidou-Kogetsidis, Maria, and Helen Woodfield, eds. 2012. Interlanguage Request Modification. Amsterdam/Philadelphia: John Benjamins Publishing.

Faerch, Claus, and Gabriele Kasper. 1989. "Internal and External Modification in Interlanguage Request Realization." In Cross-cultural Pragmatics: Requests and Apologies, edited by Shoshana Blum-Kulka, Juliane House, and Gabriele Kasper, 221-47. Norwood, NJ: Ablex. 
Félix-Brasdefer, César J. 2007. "Pragmatic Development in the Spanish as a FL classroom: A Cross-Sectional Study of Learner Requests." Intercultural Pragmatics 4 (2): 253-86.

Flores Salgado, Elizabeth. 2008. "A Pragmatic Study of Developmental Patterns in Mexican Students Making English Requests and Apologies." PhD diss., Macquarie University.

Göy, Elif, Deniz Zeyrek, and Bahar Otcu. 2012. "Developmental Patterns in Internal Modification of Requests. A Quantitative Study on Turkish Learners of English.” In Interlanguage Request Modification, edited by Maria Economidou-Kogetsidis, and Helen Woodfield, 51-86. Amsterdam/Philadelphia: John Benjamins Publishing.

Halupka-Rešetar, Sabina. 2014. "Request Modification in the Pragmatic Production of Intermediate ESP Learners." ESP Today 2 (1): 29-47.

Hassal, Tim. 2012. "Request Modification by Australian Learners of Indonesian." In Interlanguage Request Modification, edited by Maria Economidou-Kogetsidis and Helen Woodfield, 203-42. Amsterdam/ Philadelphia: John Benjamins Publishing.

Hill, Thomas. 1997. “The Development of Pragmatic Competence in an EFL Context.” PhD diss., Temple University.

Kasper, Gabriele, and Kenneth Rose. 2002. Pragmatic Development in a Second Language. Oxford: Blackwell.

Leech, Geoffrey N. 1983. Principles of Pragmatics. London: Longman

Martínez-Flor, Alicia. 2004. "The Effect of Instruction on the Development of Pragmatic Competence in the English as a Foreign Language Context: A Study Based on Suggestions.” PhD diss., Universitat Jaume I.

Martínez-Flor, Alicia, and Esther Usó-Juan. 2006. “Learners' Use of Request Modifiers across Two University ESP Disciplines." Ibérica 12: 23-41.

Richards, Jack C. 2006. Communicative Language Teaching Today. Cambridge: Cambridge University Press.

Rose, Kenneth R. 2000. "An Exploratory Cross-Sectional Study of Interlanguage Pragmatic Development”. Studies in Second Language Acquisition 22: 27-67.

—. 2009. "Interlanguage Pragmatic Development in Hong Kong, Phase 2." Journal of Pragmatics 41: 234564. doi:10.1016/j.pragma.2009.04.002.

Rose, Kenneth R., and Reiko Ono. 1995. "Eliciting Speech Act Data in Japanese: The Effect of Questionnaire Type.” Language Learning 45: 191-223. doi:10.1111/j.1467-1770.1995.tb00438.x.

Searle, John. 1979. Expression and Meaning: Studies in the Theory of Speech Acts. Cambridge: Cambridge University Press.

Schauer, Gila. 2009. Interlanguage Pragmatic Development (The Study Abroad Context). London/New York: Continuum International Publishing Group.

Trosborg, Anna. 1995. Interlanguage Pragmatics. Requests, Complaints and Apologies. Berlin/New York: Mouton de Gruyter.

Woodfield, Helen. 2012. “I Think Maybe I Want to Lend the Notes from You.' Development of Request Modification in Graduate Learners." In Interlanguage Request Modification, edited by Maria EconomidouKogetsidis, and Helen Woodfield, 9-50. Amsterdam/Philadelphia: John Benjamins Publishing.

Woodfield, Helen, and Maria Economidou-Kogetsidis, eds. 2012. Interlanguage Request Modification. Amsterdam/Philadelphia: John Benjamins Publishing. 


\section{Appendix 1. Final Questionnaire (English Version)}

Instructions: Imagine that you are in the English class and you have to speak only English. There are 10 situations below in which you want to ask your friends or teacher to do something for you. The teacher will read each situation one at a time. After each situation is read, think about what you have heard and say what you think you would say in each situation. If you don't know what you would say, simply say 'I don't know'.

1. You want to ask your classmate to lend you his/her glue. What would you say?

2. You want to ask your teacher whether he/she could postpone a written exam. What would you say?

3. You want to invite your classmate to your birthday party. What would you say?

4. You want to ask your classmate to give you his/her notebook. What would you say?

5. You want to ask your teacher to repeat his/her question. What would you say?

6. You want to ask your classmate if he/she could help you with maths. What would you say?

7. You want to invite your classmate to sit with you in your desk. What would you say?

8. You want to ask your teacher whether he/she could postpone an oral exam. What would you say?

9. You want to ask your teacher if you could volunteer for an oral exam. What would you say?

10. You want to ask your classmate to clean the blackboard instead of you. What would you say? 